\title{
Permaafan Dan Diat Alternatif Pidana Penjara Pada Tindak Pidana Pembunuhan Biasa (Doodslag)
}

\author{
Hambali Yusuf, Topo Santoso, dan Nashriana \\ Fakultas Hukum Universitas Sriwijaya Palembang \\ Fakultas Hukum Universitas Indonesia \\ Fakultas Hukum Universitas Sriwijaya Palembang \\ Jl. Srijaya Negara Bukit Besar Palembang. \\ Jl. Prof. Mr. Djokosoetono Pondok Cina Beji Depok City West Java 16424. \\ Jl. Srijaya Negara Bukit Besar Palembang \\ hambaliyusuf@ymail.com; santosox@ui.ac.id; nashriana_zaks@yahoo.co.id
}

Received: 17 Maret 2021; Accepted: 27 Juli 2021; Published: 25 Agustus 2021

DOI: 10.20885/iustum.vol28.iss2.art7

\begin{abstract}
The purpose of this study is to first, find the argument that forgiveness and punishment are needed as an alternative to other sanctions from imprisonment for the crime of murder. Second, to explain the criminal system in the application of forgiveness and punishment to ordinary murders in Islamic criminal law. Third, outlining/analyzing the policy of criminalizing the sanctions of Forgiveness and Diat on the crime of murder in the renewal of criminal sanctions. This type of research is a normative research. The approach is a statutory approach and a comparative approach as well as a philosophical approach. The results of the study conclude that first, an alternative to imprisonment is needed for ordinary murder. The application of forgiveness and punishment as an alternative to imprisonment for the crime of murder has a strong basis, both theoretically, philosophically, juridically, sociologically, and even the constitutional basis of the 1945 Constitution of the Republic of Indonesia. Second, in the application of forgiveness and punishment, the judge will apply it if there is forgiveness from the family victim. Third, as a renewal of sanctions, forgiveness and punishment are not a guide for judges, but as reasons for not imposing imprisonment, and choosing to impose an alternative fine to imprisonment, it is necessary to include it in the Draft Law on the Criminal Code which will be discussed. by the legislature.
\end{abstract}

Key Words: Clemency; criminal acts of ordinary murder (doodslag); criminal law reform; diat; imprisonment

\section{Abstrak}

Tujuan penelitian ini untuk, pertama, menemukan argumentasi diperlukan permaafan dan diat sebagai alternatif sanksi lainnya dari pidana penjara pada tindak pidana pembunuhan. Kedua, menjelaskan sistem pemidanaan dalam penerapan permaafan dan diat pada pembunuhan biasa dalam hukum pidana Islam. Ketiga, menguraikan/menganalisis kebijakan kriminalisasi sanksi permaafan dan diat pada tindak pidana pembunuhan dalam pembaharuan sanksi hukum pidana. Jenis penelitian ini adalah penelitian normatif. Pendekatan yang digunakan adalah pendekatan perundang-undangan dan pendekatan perbandingan serta pendekatan filosofis. Hasil penelitian menyimpulkan pertama, diperlukan alternatif pidana penjara pada tindak pidana pembunuhan biasa. Pemberlakuan permaafan dan diat sebagai alternatif pidana penjara pada tindak pidana pembunuhan mempunyai landasan yang kuat, baik secara teoritis, filosofis, yuridis, sosiologis, bahkan landasan konstitusional UUD RI 1945. Kedua, dalam penerapan permaafan dan diat, hakim akan menerapkannya apabila adanya permaafan dari keluarga korban. Ketiga, sebagai pembaharuan sanksi, maka permaafan dan diat bukan sebagai pedoman hakim, tetapi sebagai alasan tidak menjatuhkan pidana penjara, dan memilih menjatuhkan pidana denda alternatif pidana penjara, maka perlu dimasukkan ke dalam Rancangan Undang-Undang Kitab Undangundang Hukum Pidana yang akan dibahas oleh legislatif.

Kata-kata Kunci: Permaafan; diat; penjara; tindak pidana pembunuhan biasa (doodslag); pembaharuan hukum pidana 


\section{Pendahuluan}

Pidana penjara sebagai ancaman pidana ada dalam banyak peraturan perundang-undangan. ${ }^{1}$ Data Badan Pembinaan Hukum Nasional BPHN menunjukkan sepanjang reformasi ada 654 tindak pidana yang diancam dengan pidana penjara. Dalam KUHP sendiri pidana penjara disebut sebanyak 485 kali. Barda Nawawi Arief menyebut terdapat 575 delik yang diancam pidana penjara dari $587^{2}$ delik kejahatan di KUHP (kurang lebih 97,96\%), baik yang dirumuskan secara tunggal maupun dirumuskan secara alternatif dengan jenis-jenis pidana lainnya. ${ }^{3}$ Jadi bisa dikatakan hampir semua tindak pidana yang ada di Indonesia, itu diancam dengan pidana penjara, 4 yang akan bermuara pada penjatuhan pidana penjara oleh hakim yang berlebihan.

Kecenderungan menjadikan pidana penjara sebagai pidana pokok terlihat dalam RUU KUHP. Dari 555 pasal yang mengatur tentang pidana dalam Buku II RUU KUHP, ada 1.251 perbuatan pidana. Jumlah perbuatan pidana yang diancam pidana penjara mencapai porsi paling besar yaitu 1.154 perbuatan pidana, disusul pidana denda untuk 882 perbuatan pidana. Pola ini mengindikasikan penggunaan pidana penjara masih merupakan pilihan utama untuk mengontrol perbuatan pidana. ${ }^{5}$ Ada pula 44 perbuatan pidana yang diancam hukuman penjara seumur hidup dan 37 perbuatan pidana yang diancam hukuman mati. Jika dijumlahkan pidana penjara sementara dan pidana seumur hidup maka pidana penjara mencapai 1.198.6

Barda Nawawi Arief menguraikan tentang kebijakan legislatif dalam penanggulangan kejahatan dengan pidana penjara sebagai berikut:

1. Dalam merumuskan pidana penjara terhadap tindak pidana kejahatan, terlihat garis kebijakan legislatif di dalam KUHP yaitu:

${ }^{1}$ https://www.voaindonesia.com/a/jumlah-napi-membludak-pemerintah-diminta-optimalkan-alternatifpemidanaan-non-pemenjaraan/4807236.html, diakses 14 September 2020

2 Menurut Barda Nawi Arif perhitungan jumlah perumusan tidak hanya didasarkan pada jumlah pasal, tetapi juga pada perumusan delik dalam tiap ayat. (periksa Barda Nawawi Arief, Kebijakan Legislatif dalam Penanggulangan Kejahatan Dengan Pidana Penjara, Universitas Diponegoro, Semarang, 1994, hlm. 69

${ }^{3}$ Ibid., hlm. 70

4 "Genoveva Alicia dalam konferensi pers di Jakarta" .https://www.voaindonesia.com/a/jumlah-napimembludak-pemerintah-diminta-optimalkan-alternatif-pemidanaan-non-pemenjaraan/4807236. html., diakses 14 September. 2020.

${ }^{5}$ Supriyadi W. Eddyono Direktur Eksekutif ICJR. Diskusi kriminal dalam RKUHP dan bom waktu overcrowded Lapas di Jakarta, Rabu (15/11). 2017. https://www.voaindonesia.com/a/banyak-aturan-pidanapenyebab-penjara-kelebihan-penghuni-/4116337. html. Diakses 14 Oktober 2020.

${ }^{6}$ Ibid. 
a. Pidana penjara merupakan jenis sanksi yang paling banyak diancamkan terhadap tindak pidana kejahatan (tercantum pada sekitar $98 \%$ perumusan delik), berarti hampir semua tindak pidana kejahatan diancam dengan pidana penjara;

b. Pidana penjara yang diancamkan terhadap tindak pidana kejahatan itu dirumuskan secara tunggal dan secara alternatif, tetapi sebagian besar (sekitar 70\%) dirumuskan secara imperatif dalam bentuk tunggal;

c. Sistem perumusan tunggal itu terdapat hampir pada setiap kelompok kejahatan (yaitu terdapat pada 29 kelompok kejahatan) dari 31 bab atau kelompok kejahatan di dalam KUHP;

d. Dalam hal pidana penjara dirumuskan alternatif, paling banyak dialternatifkan dengan pidana denda (sekitar 20\% perumusan delik) yang pada umumnya relatif ringan (maksimum pidana denda yang paling banyak dicantumkan hanya Rp. 4.500,-);

2. Garis kebijakan legislatif yang terlihat pada undang-undang di luar KUHP dalam merumuskan pidana penjara terhadap delik pidana kejahatan dapat diidentifikasi sebagai berikut:

a. Pidana penjara merupakan jenis sanksi pidana yang paling banyak diancamkan terhadap tindak pidana kejahatan (tercantum dalam sekitar $92 \%$ perumusan delik);

b. Pidana penjara yang diancamkan itu dirumuskan secara tunggal, alternatif, kumulatif dan secara kumulatif-alternatif. Sistem perumusan yang paling banyak digunakan ialah: pertama, sistem perumusan kumulatif-alternatif berupa ancaman pidana penjara dan/atau denda (sekitar 23\%); kedua, perumusan alternatif berupa pidana penjara atau denda" (sekitar 21\%); dan ketiga, perumusan tunggal berupa ancaman pidana penjara (sekitar 20\%);

c. Walaupun sistem perumusan tunggal hanya merupakan urutan ketiga dari yang paling banyak digunakan, namun dengan adanya perumusan kumulatif (sekitar 10\%) yang juga bersifat imperatif dan adanya perumusan kumulatif-alternatif (sekitar 23\%) yang mengandung sifat imperatif terselubung, maka perumusan ancaman pidana penjara secara imperatif merupakan perumusan yang paling dominan;

3. Garis kebijakan legislatif dalam perumusan pidana penjara seperti tersebut pada angka 1 dan 2 di atas, adalah faktor formal yang memberi peluang demikian besar dijatuhkan pidana pejara dalam praktek peradilan.

4. Sistem perumusan ancaman pidana penjara secara imperatif (terutama perumusan tunggal dan kumulatif) merupakan faktor utama banyaknya pidana penjara yang dijatuhkan tidak atas dasar pertimbangan rasional, yaitu hanya berorientasi pada orang. ${ }^{7}$

Pengaturan sanksi pidana penjara yang berlebihan akan bermuara pada penjatuhan pidana penjara yang berlebihan. Data penghuni penjara pelaku tindak 
pidana 2021, jumlah tahanan dan narapidana di Lapas seluruh Kantor Wilayah Kementrian Hukum dan Hak Asasi Manusia per 2021 yaitu 270.858 orang, sedangkan Kapasitas penjara: 135.981 orang, berarti melebihi kapasitas daya tampung Lapas 134,877 orang atau 99 persen. Data terakhir per Juni 2021 jumlah penghuni penjara perkanwil Hukum dan HAM seluruh Indonesia, terdapat 33 Kanwil, hanya 3 kanwil yang jumlah penghuninya tidak melebihi kapasitas, berarti 30 kanwil melebihi jumlah penghuni. ${ }^{8}$ Hal ini dikarenakan besarnya persentase penggunaan pidana penjara dalam peraturan perundang-undangan dan penjatuhan pidana penjara. Data ini merupakan cerminan dari akibat kebijkan perumusan pidana penjara yang berlebihan, yang bermuara pada putusan hakim pidana penjara yang berlebihan pula.

Problem yang muncul dari kelebihan dari penghuni Lapas adalah masalah pembinaan yang tidak optimal dan fotensial munimbulkan criminogen atau memunculkan kejahatan baru dari pelaksanaan sistem pembinaan yang buruk. Kondisi dasar tersebut melahirkan beragam dampak negatif, kepadatan penghuni menghambat pengelolaan nara pidana di dalam tahanan.

Dari segi pembiayaan masalah yang muncul akibat dari penggunaan pidana penjara yang berlebihan adalah bahwa penjara yang penuh sesak menimbulkan dampak negatif, antara lain membengkaknya anggaran makanan untuk para narapidana dan anggaran pembangunan infrastruktur. ${ }^{9}$

Kasus pembakaran yang pernah terjadi di Lembaga Pemasyarakatan Kerobokan Bali 24 April 2016, di Bengkulu 25 Maret 2016, di Malabero 25 Maret 2016, kerusuhan di lapas Banceuy Bandung, kerusuhan di lapas Tanjung Gusta Medan, Lapas Kuala Simpang Aceh (1 April 2016), di Riau, dan di tempat lainnya salah satu penyebabnya adalah kelebihan penghuni. TV One memberitakan kerusuhan narapidana narkoba di Lapas kelas I.A Cirebon Jawa Barat mengamuk ketika kamar-kamar sel mereka dirazia ada indikasi banyak alat-alat komunikasi terdapat di dalam kamar tahanan mereka. ${ }^{10}$

${ }^{8}$ Sistem data base pemasyarakatan", http://smslap.ditjenpas.go.id/, diakses 18 Juni 2021

9 Dirjenpas Kemenkumham, Lenggono, https://www.voaindonesia.com/a/jumlah-napi-membludakpemerintah-diminta-optimalkan-alternatif-pemidanaan-non-pemenjaraan/4807236.html. Ibid.

10 TV One, Berita Sore, Rabu, 21 Maret 2018 
Lembaga pemasyarakatan tetap menjadi school of crime bagi warga binaan. Prisonisasi terhadap warga binaan sulit untuk dihindari, terlebih jika pengawasan oleh petugas tidak dilakukan secara optimal. Warga binaan yang tadinya dipidana karena pencurian ringan, setelah menjalani masa hukuman di lembaga pemasyarakatan dan kembali ke masyarakat dapat melakukan kejahatan yang lebih besar seperti penjualan narkotika. Hal ini disebabkan karena narapidana telah belajar melakukan kejahatan selama berada di dalam lembaga pemasyarakatan. Kejahatan seperti penjualan narkotika, penganiayaan dan judi juga dilakukan di dalam lembaga pemasyarakatan. Berdasarkan survei Kompas 2016 hampir separuh responden (48,7 \%) berpendapat, Lapas saat ini cenderung berfungsi sebagai sekolah kriminal ketimbang tempat pembinaan nara pidana. Pelaku kriminal yang di penjara justru semakin pintar berbuat kejahatan yang lebih besar. Hal ini antara lain disebabkan dicampurnya narapidana kejahatan biasa (konvensional) dengan narapidana yang melakukan kejahatan luar biasa. ${ }^{11}$

Langkah yang harus ditempuh adalah bagaimana mengurangi penjatuhan pidana penjara. Untuk itu kebijakan yang paling moderat adalah memberikan sanksi alternatif terhadap sanksi pidana penjara kepada hakim untuk mengadakan pilihan menjatuhkan sanksi lain daripada penjara. Sanksi permaafan dan diat sebagai pengganti sanksi qisahs pada tindak pembunuhan sengaja dalam hukum pidana Islam dapat dijadikan sebagai kebijakan sanksi baru dalam perumusan pidana alternatif penjara pada tindak pidana pembunuhan biasa (doodslag).

\section{Rumusan Masalah}

Berdasarkan latar belakang permasalahan tersebut, maka diajukan permasalahan yang akan dikaji dalam penelitian ini, pertama, mengapa permaafan dan diat diperlukan sebagai alternatif pidana penjara pada tindak pidana pembunuhan biasa? Kedua, bagaimana penerapan permaafan dan diat sebagai alternatif pidana penjara pada tindak pidana pembunuhan biasa? Ketiga, bagaimana permaafan dan diat dapat dijadikan sebagai alternatif pidana penjara

11 Kompas, Lembaga pemasyarakatan tetap menjadi school of crime, 4 April 2016 
pada tindak pidana pembunuhan biasa dalam pembaharuan jenis sanksi pidana Indonesia?

\section{Tujuan Penelitian}

Berdasarkan rumusan masalah di atas, maka tujuan penelitian ini yaitu: pertama, memberikan alasan-alasan yang kuat sehingga Permaafan dan Diat diperlukan sebagai sanksi alternatif bagi pidana penjara pada tindak pidana pembunuhan. Kedua, menjelaskan sistem pemidanaan dalam penerapan Permaafan dan Diat pada pembunuhan biasa dalam hukum pidana Islam. Ketiga, menguraikan/menganalisis kebijakan kriminalisasi sanksi Permaafan dan Diat pada tindak pidana pembunuhan dalam pembaharuan sanksi hukum pidana.

\section{Metode Penelitian}

Jenis penelitian ini adalah penelitian normatif, 12 yaitu penelitian yang dilakukan dengan cara meneliti bahan pustaka atau data sekunder. Pendekatan dalam penelitian hukum normatif yang menggunakan pendekatan perundangundangan dan pendekatan perbandingan serta pendekatan filosofis. Pendekatan perundang-undangan dilakukan dengan menelaah semua undang-undang dan regulasi yang bersangkut paut dengan isu hukum yang diketengahkan. ${ }^{13}$ Pendekatan perbandingan adalah dengan melakukan perbandingan hukum. Pendekatan filosofis adalah pendekatan pilsafat, khsusunya nilai-nilai Pancasila sebagai yang dipelihara dan dipraktikkan dalam kehidupan berbangsa dan bernegara di Indonesia.

\section{Hasil Penelitian dan Pembahasan} Permaafan dan Diat Sebagai Alternatif Pidana Penjara pada Tindak Pidana
Pembunuhan Biasa

Berangkat dari kelemahan, kekurangan dan kegagalan pidana penjara, yang berawal dari kebijakan penetapan pidana penjara secara tunggal yang paling banyak, dan berakibat pada penjatuhan pidana penjara yang paling banyak pula. Karenanya pidana penjara paling banyak menyumbang narapidana di lembaga

12 Soerjono Soekanto, et al, Penelitian Hukum Normatif, Raja Grafindo, Jakarta, 1995, hlm. 13 hlm. 93

13 Peter Mahmud Marzuki, Penelitian Hukum, Prenadamedia Group, Edisi revisi, Cet. Ke.7, Jakarta, 2014, 
pemasyarakatan yang menyebabkan penjara melebihi daya tampung (overcapacity), dan menyulitkan pembinaan para nara pidana, yang berpengaruh pada tidak tercapai tujuan penjatuhan pidana, yang berpotensi terjadinya criminogen (memunculkan kejahatan baru akibat penyelenggaranaan Sistem Peradilan Pidana yang salah), maka pidana penjara perlu sanksi alternatif lain.

Sanksi alternatif yang ditawarkan adalah sanksi permaafan dan diat sebagai sanksi pengganti qishas pada tindak pidana pembunuhan sengaja qishas-diat. Sebagai mana juga yang ada dalam ketentuan Pasal 338 KUHP Indonesia. Untuk itu diperlukan argumentasi yang kuat, sejauh mana konsep permaafan dalam qishsas diat dalam hukum pidana Islam dapat ditarik untuk dijadikan rumusan dalam rangka pembaharuan hukum pidana nasional terhadap kasus pembunuhan. Menurut Jimly Asshiddiqie, kemungkinan sumbangan tradisi pidana Islam itu dalam rangka pembentukan hukum pidana nasional, perlu diperhatikan beberapa ukuran sebagai berikut:

a. Apakah dan sejauh manakah usaha itu sejalan dengan perkembangan teori modern mengenai pemidanaan.

b. Apakah dan sejauh mana usaha adopsi itu mempunyai dasar-dasar yang bersifat filosifis, khususnya apabila diukur dengan cita-cita hukum berdasarkan Pancasila.

c. Apakah dan sejauh mana usaha melakukan adopsi tradisi pidana Islam itu memiliki landasan-landasan yang bersifat yuridis.

d. Apakah dan sejauh mana kemungkinan bahwa usaha itu dapat memperoleh dukungan sosio-kultural dan situasi masyarakat Indonesia yang majekmuk. ${ }^{14}$

\section{a. Relevansi dengan Perkembangan Teori Pemidanaan Modern}

Relevansi permaafan qishas-diat dengan kecenderungan perkembangan hukum pidana moderen sekarang. Menurut Jimly Asshiddiqie, ada beberapa kecenderungan dalam perkembangan hukum pidana sekarang: 15

Ada kecenderungan umum bahwa sistem hukum modern sekarang ini tidak lagi berusaha memisahkan secara tegas perbedaan antara hukum pidana dengan hukum perdata. Baik dalam rangka penuntutannya maupan dalam sistem sanksi hukumnya. Hal ini sejalan dengan tradisi hukum Islam, yang untuk hal-hal

${ }^{14}$ Jimli Ashshiddiqie, Pembaharuan Hukum Pidana Indonesia, Angkasa Bandung, 1995, hlm. 159

15 Ibid., hlm. 25 
tertentu seperti dalam pristiwa pidana pembunuhan dan perlukaan, unsur perbuatan hukumnya tetap diakui dan diatur sebagaimana mestinya. Namun kepentingan korban tentap dilindungi secara nyata. Demikian juga sifat hukum adat, peristiwa atau perbuatan delik adat itu menyeluruh dan menyatukan, artinya tidak memisahkan antara delik yang bersifat pidana atau bersifat perdata.

Sejalan dengan kecenderungan pertama, maka sistem sanksi ganti kerugian dalam pristiwa pidana juga mulai dikembangkan. Artinya, sistem hukum kontemporer, mulai memberikan perhatian kepada kepentingan korban dalam pristiwa-pristiwa pidana tertentu. Namun, perhatian kepada kepentingan korban itu, hingga sekarang masih belum seimbang, apabila dibandingkan dengan perkembangan perhatian kepada tersangka atau terpidana. Ketimpangan perhatian itu dapat dilihat dalam hal-hal berikut:

1. Dari sudut kepentingan tersangka, terdakwa, atau terpidana, terdapat kecenderungan yang kuat dalam berbagai teori ilmu hukum modern untuk semakin memperhatikan kepentingan mereka. Dari segi terdakwa, bahkan muncul pendekatan ilmiah yang disebut "The defendant's persfektives". Sementara itu, dari sudut terpidana, muncul berbagai teori yang secara ekstrim merekondasikan dihapusnya pidana mati, disederhanakan dan dimanusiawikannya lembaga penjara, dan bahkan ada pula yang mengusulkan supaya pidana penjara itu sendiri dihapuskan.

2. Dari segi institusi pidana (sanksi pidana) nya sendiri, ketidak seimbangan perhatian terhadap kepentingan korban dan pelaku delik itu juga masih terlihat dalam pengelompokan pidananya. Dalam konsep RUU KUHP per Septembaer 2019 , Pidana terdiri atas, Pasal 64 Pidana terdiri atas:

a. pidana pokok;

b. pidana tambahan; dan

c. pidana yang bersifat khusus untuk Tindak Pidana tertentu yang ditentukan dalam undang-undang.

Pasal 65:

(1) Pidana pokok sebagaimana dimaksud dalam Pasal 64 huruf a terdiri atas:
a. pidana penjara;
b. pidana tutupan;
c. pidana pengawasan; 
d. pidana denda; dan

e. pidana kerja sosial.

(2) Urutan pidana sebagaimana dimaksud pada ayat (1) menentukan berat atau ringannya pidana.

Perhatian kepada korban terdapat dalam institusi pidana ganti rugi yang dirumuskan sebagai pidana tambahan yaitu hanya pembayaran ganti rugi kepada korban, yang diatur dalam RUU KUHP per September 2019, Pasal 66 huruf b yang dapat dijatuhkan kepada pembuat terdiri atas Pasal 66 ayat (1):

1. pencabutan hak tertentu;

2. perampasan Barang tertentu dan/atau tagihan;

3. pengumuman putusan hakim;

4. pembayaran ganti rugi;

5. pencabutan izin tertentu; dan

6. pemenuhan kewajiban adat setempat atau kewajiban menurut hukum yang hidup dalam masyarakat.

Perhatian terhadap terpidana tercermin dalam kategorisasi pidana mati sebagai pidana pokok yang bersifat khusus. Pengkhususan pidana mati ini dilakukan dengan mengembangkan pengertian yang lebih manusiawi dengan orientasi pembinaan dan pemasyarakatan terpidana. Malahan dalam berbagai teori, terutama karena pengaruh kriminologi dan victimologi, pengertian korban kejahatan itu sendiri maupun pengertian kesalahan dalam setiap pristiwa pidana, diperluas sedemikian rupa sehingga pihak korban juga turut diperslahkan sebagai penyebab timbulnya kejahatan. Sementara perhatian kepada kepentingan korban itu sendiri belum cukup berkembang.

Ketimpangan itu erat berkaitan dengan pendekatan yang dipakai dalam merumuskan konsep sanksi pidana. Dalam teori modern, sanksi pidana dilihat terlepas bentuk atau jenis kejahatan atau objek yang diancam dan jenis kejahatan yang dilakukan pelaku. Karena itu, sistem pidana Islam secara mudah dapat memberikan perhatian yang seimbang baik kepada pelaku kejahatan (tersangka, terdakwa, atau terpidana) maupun kepada korban kejahatan itu. Sejauh menyangkut ketimpangan tersebut, maka tradisi pidana Islam dapat dijadikan contoh dalam rangka pembentukan KUHP baru. 


\section{b. Relevansi Filosofis}

Seperti dimaklumi tolok ukur praktis mengenai filsafat hukum Indonesia tidak lain adalah Pancasila sebagai abstraksi dari nilai-nilai luhur kehidupan manusia Indonesia, yang di dalamnya terkandung cita-cita hukum bangsa. Kelima sila Pancasila meliputi sila Ketuhanan Yang Maha Esa, sila Kemanusiaan yang adil dan beradab, sila Persatuan Indonesia, sila Kerakyatan yang dipimpin oleh Hikmat kebijaksanaan dalam permusyawaratan/perwakilan, dan sila Keadilan Sosial bagi Seluruh rakyat Indonesia. Di antara kelima sila itu, sila Ketuhanan Yang Maha Esa, merupakan sila pertama dan sekaligus merupaka sila yang utama. Sila pertama ini menyinari, mengayomi, memimpin, dan mempersatukan keempat Sila lainnya. ${ }^{16}$

Sistem hukum berdasarkan Pancasila itu, pertama-tama adalah sistem hukum yang relegius. Seperti halnya negara Indonesia yang sering dikatakan sebagai bukan negara sekuler dan bukan negara agama dalam arti negara dari suatu agama tertentu, maka sistem hukumnya juga bukan sistem hukum agama tertentu, tetapi juga bukan sistem hukum yang mengabaikan agama atau sekuler. Karena itu, lebih sesuai apabila dikatakan bahwa negara Republik Indonesia adalah negara yang agamais (religius), bukan negara agama. Sedangkan sistem hukumnya adalah sistem hukum yang juga relegius, bukan sistem hukum dari agama tertentu. ${ }^{17}$

Bentuk-bentuk tradisi hukum Islam bisa diterima sebagai bahan hukum pidana nasional. Persoalan lain adalah bagaimana kaidah-kaidah hukum Islam dapat ditransformasi kedalam hukum nasional, adalah persoalan metodelogis ilmiah. Transformasi unsur hukum pidana Islam qishas- diat dengan permaafan sudah berjalan dan masuk ke dalam rumusan beberapa undang-undang hukum pidana seperti undang-undang sistem peradilan anak, walaupun gagasan permaafan ini tidak dijadikan sebagai alasan pembebesan dari hukuman pidana.

Nilai-nilai yang mendasari hukum nasional adalah Pancasila yang merupakan cita hukum (gagasan hukum nasional) ${ }^{18}$. Dalam tradisi hukum pidana

${ }^{16}$ Ibid., hlm. 189

17 Ibid

18 A. Hamid S Attamami, "Pancasila Cita Hukum dalam Kehidupan Hukum Bangsa Indonesia", Makalah BP-7, 1991 
Islam unsur hukum pidana permaafan merupakan cita hukum dari nilai sila Ketuhanan Yang Maha Esa. Dalam berbagai ketentuan hukum pidana gagasan permaafan ini sudah diadopsi ke dalam hukum pidana nasional.

\section{c. Relevansi Yuridis}

Teori validitas hukum merupakan salah satu teori yang mengajarkan bagaimana dan apa syarat-syaratnya agar suatu kaidah hukum menjadi legitimate dan sah (valid) berlakunya, sehingga dapat diberlakukan kepada masyarakat, bila perlu dengan paksa, yakni suatu kaidah hukum yang memenuhi persyaratan-persyaratan sebagai berikut:

1. Kaidah hukum tersebut haruslah dirumuskan ke dalam berbagai bentuk aturan formal, seperti dalam bentuk pasal-pasal dari Undang-Undang Dasar, undang-undang dan berbagai bentuk peraturan lainnya, aturanaturan internasional seperti dalam bentuk traktat, konvensi, atau setidaknya dalam bentuk adat kebiasaan;

2. Aturan formal tersebut harus dibuat secara sah, misalnya jika dalam bentuk undang-undang harus dibuat oleh oleh parlemen (bersama dengan pemerintah);

3. Secara hukum, aturan hukum tersebut tidak mungkin dibatalkan;

4. Terhadap aturan formal tersebut tidak ada cacat yuridis lainnya. Misalnya tidak bertentangan dengan peraturan yang lebih tinggi;

5. Kaidah hukum tersebut harus dapat diterapkan oleh badan-badan penerap hukum, seperti pengadilan, kepolisian, kejaksaan;

6. Kaidah hukum tersebut harus dapat diterima dan dipatuhi oleh masyarakat;

7. Kaidah hukum tersebut haruslah sesuai jiwa bangsa yang bersangkutan. ${ }^{19}$

Relevansi yuridis tradisi hukum pidana Islam dari unsur pidana qishas-diat dengan "permaafan" dalam hukum nasional Indonesia dapat ditelusuri dalam bebarapa ketentuan undang-undang dan peraturan lainnya yang mengatur tentang perdamain antara lain :

1. Undang-Undang Nomor 1 Tahun 1946 tentang Kitab Undang-Undang Hukum Pidana juncto Undang-Undang Nomor 73 Tahun 1958 (KUHP), dalam Pasal 82 menjelaskan kewenangan/ hak menuntut delik pelanggaran itu hapus, apabila terdakwa telah membayar denda maksimum untuk delik pelanggaran itu,yang dikenal dengan istilah "afkoop" atau "pembayaran denda damai" hlm. 110

${ }_{19}$ Munir Fuady, Teori-teori besar dalam Hukum (grand Theori), Kencana Prenadamedia Group, Jakarta, 2013, 
2. Undang-Undang Nomor 39 Tahun 1999 tentang Hak Asasi Manusia, dalam Pasal 1 ayat (7) menjelaskan adanya kewenangan Komnas HAM untuk melakukan mediasi terhadap kasus pelanggaran HAM.

3. Undang-Undang Nomor 2 Tahun 2002 tentang Kepolisian Republik Indonesia, menjelaskan adanya kewenangan diskresi kepolisian pada Pasal 18.

4. Undang-Undang Nomor 22 Tahun 2009 tentang Lalu Lintas dan Angkutan Jalan, berdasarkan Pasal 236, pihak yang menyebabkan kecelakaan lalu lintas diwajibkan memberikan ganti kerugian dan dapat dilakukan kesepakatan damai diluar pengadilan.

5. Undang-Undang Nomor 11 Tahun 2012 tentang Sistem Peradilan Pidana Anak (UU SPPA), mengenal adanya diversi yaitu pengalihan proses perkara pidana diluar pengadilan untuk pelaku kategori anak. ${ }^{20}$

6. Peraturan Mahkamah Agung (PERMA) Nomor 2 Tahun 2012 tentang Penyesuaian Batasan Tindak Pidana Ringan dan Jumlah Denda dalam KUHP, menentukan pencurian dibawah Rp. 2.500.000,- tidak dapat ditahan.

7. Surat Kapolri No. Pol: B/3022/XII/2009/SDEOPS tentang Penanganan Kasus Melalui Alternatif Dispute Resolution (ADR), Surat kapolri ini memerintahkan penyidik untuk menyaring perkara mana yang harus dilimpahkan ke kejaksaan dan mana yang lebih baik diselesaikan melalui ADR sebagai perwujudan restorative justice

8. Dalam Rancangan KUHP Pasal 60 hurup j dan k : Dalam pemidanaan wajib dipertimbangkan pemaafan dari korban dan/atau keluarganya; dan/atau nilai hukum dan keadilan yang hidup dalam masyarakat. Dalam konsep RUKUHP, perdamaian hanya dijadikan dasar pertimbangan hakim yang dapat meringankan saja dan bukan sebagai dasar atau alasan melepaskan tuntutan pemidanaan.

Beberapa ketentuan tersebut memberi kemungkinan adanya penyelesaian perkara pidana di luar pengadilan, namun bagaimanapun juga belum secara

${ }^{20}$ Lihat Ps. 6 UU No. 11 Tahun 2012 tentang Sistem Peradilan Anak (SPPA). Diversi bertujuan: a. mencapai perdamaian antara korban dan Anak;

b. menyelesaikan perkara Anak di luar proses peradilan;

c. menghindarkan Anak dari perampasan kemerdekaan;

d. mendorong masyarakat untuk berpartisipasi; dan

e. menanamkan rasa tanggung jawab kepada Anak 
eksplisit dan tegas mengatur mengenai mediasi penal. Namun yang perlu ditegaskan di sini adalah bahwa dalam arah perkembangan pengaturan pidana permaafan dengan perdamaian telah diatur dalam peraturan hukum pidana walaupun belum dapat menghapuskan pidana.

Kemungkinan untuk memberlakukan tradisi hukum Islam itu sebagai bahan hukum nasional di Indonesia, juga didukung oleh landasan juridis yang cukup kuat. Ketentuan Pasal 29 UUD 1945 merupakan landasan yuridis konstitusional yang mendasar untuk menjadikan tradisi Islam mengenai bentuk-bentuk pidana itu sebagai bahan hukum yang sah.

Berbagai taradisi hukum Islam yang berlaku sebagai hukum positif di Indonesia lebih banyak ketentuan bidangn hukum keperdataan, seperti hukum perkawinan, hukum kewarisan, hukum wakap, hukum perbankan, dan lain-lain. Hanya saja, keberadaan taradisi hukum Islam itu, baik yang bersifat pidana maupun hukum keperdataan, tidak harus dilihat dari segi bentuk teknisnya, misalnya hukum pidana atau keperdataan. Yang perlu dikembangkan menjadi bahan perumusan hukum pidana nasional, adalah gagasan-gagasan inti dari ketentuan-ketentuan teknis hukum pidana Islam itu. ${ }^{21}$ Dengan demikian, bahkan tidak ada persoalan mengenai kemungkinan perbedaan-perbedaan pandangan antara penduduk yang beragama Islam dengan golongan non muslim itu.

Mengikuti cara berpikir teori legitimasi dan validitas hukum bahwa suatu kaidah hukum menjadi legitimate dan sah (valid) berlaku harus memenuhi persyaratan-persyaratan. Semua ketentuan peraturan perundang-undangan yang berlakukan permaafan berlaku secara sah (valid), telah memenuhi semua persyaratan yang diminta teori ini. Pemberlakuan ketentuan permaafan dalam berbagai undang-undang pidana seperti telah disebut di atas memang tidak atau bukan sebagai alasan pelepasan tuntutan pemidanaan. Namun demikian ada petunjuk yang akan menuntun kita ke satu kesimpulan logis tentang gagasan permaafan dalam hukum pidana Islam ada relevansinya dalam berbagai ketentuan perundang-undang hukum pidana nasional di Indonesia.

${ }^{21}$ Jimly Asshiddiqie, Pembaharuan Hukum Pidana..., Op. Cit., hlm. 195 


\section{d. Relevansi Sosiologis}

Untuk menganalisis relevansi permaafan dalam fiqh jinayat apakah mempunyai relevansi secara sosiologis, akan digunakan pisau analisis teori Validitas dan Efektivitas Hukum dan teori Receptio A contrario. Sebenarnya banyak teori dalam hukum Islam yang dapat dipakai untuk menganalisis keberadaan dan keberlakuan hukum Islam di Indonesia. Seperti teori Kredo atau Syahadat, Teori Receptio in Complexu, Teori receptie, teori Receptie Exit.

Jalan fikiran teori Validitas adalah bahwa hukum tersebut haruslah dapat diterima oleh masyarakat. Demikian pula sebaliknya, bahwa agar diberlakukan terhadap masyarakat, maka suatu kaidah hukum haruslah merupakan hukum valid atau legatimate. ${ }^{22}$ Teori Efektifitas untuk melihat seberapa besar penerimaan dan kepatuhan masyarakat terhadap kaidah hukum Islam tentang permaafan, yang dijadikan penilaian relevansi permaafan terhadap kaidah hukum pidana positif.

Namun demikian, suatu kaidah hukum yang valid belum tentu merupakan suatu kaidah hukum yang efektif. Dalam hal ini validitas suatu norma merupakan hal yang tergolong ke dalam "yang seharusnya" (das Sollen), sedangkan "efektivitas" dari suatu norma merupakan suatu kenyataannya (das Sein). ${ }^{23}$

Hans Kelsen mempersyaratkan hubungan timbal balik antara unsur "validitas" dan "keefektifan" dari suatu kaidah hukum. Menurutnya, sebelum berlaku secara efektif, suatu norma hukum harus terlebih dahulu valid, karena jika suatu kaidah hukum tidak valid, maka hakim misalnya tidak akan menerapkan hukum tersebut, sehingga kaidah hukum tersebut tidak pernah efektif berlaku. Tetapi sebaliknya adalah benar juga bahwa keefektifan merupakan syarat mutlak bagi sebuah kaidah hukum yang valid. ${ }^{24}$ Karenanya, jika suatu masa karena perubahan masyarakat, suatu kaidah hukum yang semulanya valid dan efektif berlaku, kemudian menjadi tidak efektif lagi, maka kaidah hukum tersebut juga menjadi tidak lagi valid.

Jadi menurut Hans Kelsen, suatu aturan hukum harus dalam keadaan valid terlebih dahulu baru diketahui apakah aturan tersebut dapat menjadi efektif. Jika setelah diterapkan ternyata peraturan yang sebenarnya sudah valid tersebut

\footnotetext{
${ }^{22}$ Munir Fuady, Teori-teori Besar ..., Op. Cit., hlm. 116

${ }^{23}$ Ibid.

${ }^{24}$ Ibid.
} 
ternyata tidak dapat diterapkan atau tidak dapat diterima oleh masyarakat secara meluas dan/atau secara terus menerus, maka ketentuan hukum tersebut menjadi hilang unsur validitasnya, sehingga berubah sifat dari aturan yang valid menjadi aturan yang tidak valid. Maka dapat diterimanya dan diterapkannya suatu kaidah hukum dalam masyarakat adalah condition sine quanon bagi sah/legitimate tidaknya suatu norma hukum.

Jalan pikiran teori Receptio A Contrario, bahwa hukum adat berlaku dalam masyarakat apabila tidak bertentangan dengan hukum Islam. Teori ini memberikan validasi kepada hukum adat, bahwa hukum adat sah dan legitimate apabila telah mendapat pengakuan dari hukum Islam dan dijalankan oleh masyarakat muslim. Sebelum teori ini, berlaku teori Receptio In Complexu. Menurut teori ini bahwa di Indonesia berlaku hukum Islam secara penuh bagi pemeluknya. Oleh karena itu politik hukum dalam peradilanpun diperlakukan undang-undang agama Islam untuk penduduk asli. ${ }^{25}$

Sejalan dengan pemikiran dua teori di atas (teori Validitas dan Efektifitas Hukum dan teori Receptio A Contario), bahwa fenomena berlakunya hukum Islam di Nusantara sejak zaman kerajaan-kerajaan Islam. Adanya Peradilan Agama dalam Papakeum (kitab) Cirebon merupakan salah satu bukti. Demikian pula, Kerajaan Sultan di Aceh, Kerajaan Pasai, Pagar Ruyung, dengan Dang Tuanku Bundo kanduang, Padri dengan Imam Bonjol (Minangkabau), Demak, Pajang, Mataram, bahkan juga Malaka dan Brunei Semenanjung Melayu. ${ }^{26}$ Bidang-bidang hukum Islam yang berlaku ketika itu adalah hukum perkawinan, perwakafan, infaq dan sedekah. Kenyataan-kenyataan berlakunya hukum Islam bahwa secara sosiologis hukum Islam telah diterima dan diikuti oleh masyarakat Muslim. Bahkan berkembang sejak zaman kerajaan-kerajaan Islam, masa penjajahan kolonial Belanda, hingga zaman kemerdekaan. ${ }^{27}$

${ }^{25}$ Sayuti Thalib, Receptio A Contrario, Bina Aksara, cetakan keempat, Jakarata, 1985, hlm. 1

26 Dedi Supriyadi, Sejarah Hukum Islam (dari Kawasan Jazirah Arab Sampai Indonesia), CV Pustaka Setia, Bandung, 2007, hlm. 392

${ }^{27}$ Ibid. 
Penerapan Permaafan dan Diat Sebagai Alternatif Pidana Penjara Pada Tindak Pidana Pembunuhan Biasa (Doodslag)

Sehubungan dengan penerapan jenis sanksi qishas kepada pelaku pembunuhan sengaja dalam sistem pemidanaan hukum pidana Islam, berbeda dengan sistem pemidanaan dalam hukum pidana positif. Jika dalam sistem hukum pidana positif pengenaan pidana kepada pelaku pembunuhan, oleh jaksa menuntut terdakwa atas dakwaan tindak pidana pembunuhan karena pelanggaran Pasal 338 KUHP dengan tuntutan pidana penjara paling lama 15 tahun. Hakim dalam penerapan pasal ini tidak punya pilihan lain selain menerapkan sanksi pidana penjara, dan bebas bergerak menentukan sanki pidana dalam batas minimal umum 1 hari dan maksimal khusus 15 tahun penjara.

Pada sistem pemidanaan hukum Islam untuk penerapan sanksi qishas-diat kepada pelaku tindak pidana pembunuhan hak penuntutan berada pada pihak keluarga korban dan bukan pada jaksa penuntut umum, jika keluarga korban menuntut hukuman qishas maka hakim harus menjatuhkan hukuman qishas. Apabila keluarga korban memaafkan pelaku pembunuhan dan menuntut diat maka hakim harus memutus perkara itu dengan hukuman diat dan menghapus pidana qishas. ${ }^{28}$

Jenis sanksi qishas-diat dengan permaafan ditentukan dalam Al-Quran surat al-Baqarah ayat 178 yang berlaku bagi jarimah pembunuhan sengaja:

Hai orang-orang yang beriman, diwajibkan atas kamu qishaash berkenaan dengan orang-orang yang dibunuh; orang merdeka dengan orang merdeka, hamba dengan hamba, dan wanita dengan wanita. Maka barang siapa yang mendapat suatu pema'afan dari saudaranya, hendaklah (yang mema'afkan). mengikuti dengan cara yang baik, dan hendaklah (yang diberi ma'af) membayar diat kepada yang memberi ma'af dengan cara yang baik (pula). Yang demikian itu adalah suatu keringanan dari Tuhan kamu dan suatu rahmat. Barang siapa yang melampaui batas sesudah itu, maka baginya siksa yang sangat pedih. (QS. Al-Baqarah ayat 178)

Dalam As-Sunnah HR. Al-Tarmizi dan Al-Nasa'i: Rasulullah Saw pernah bersabda:

Barang siapa dibunuh, dia (keluarganya) bisa memilih dua hal: bisa memaafkan dan bisa melakukan qishas" (HR. Al-Tarmizi dan Al-Nasa'i). Dalam hadist lain nabi bersabda "Barang siapa menyerang seorang mukmin

28 Paisol Burlian, Implementasi Konsep Hukuman Qihsash di Indonesia, Sinar Grafika, Jakarta, 2015, hlm. 71-74 
(untuk kemudian) membunuh dengan bukti (yang benar), ia (berhak) mendapatkan qishas, kecuali jika keluarga korban ridha" (HR. Al-Nasa'i dan Al-Darimi).

Menurut Muhammad Syahrur hukuman qihsas dalam pembunuhan biasa seperti yang dijelaskan dalam Surat al-Baqarah ayat 178 adalah batas maksimal hukuman bagi seseorang yang melakukan pembunuhan yang tidak dibenarkan yaitu balas bunuh. ${ }^{29}$

Sanksi diat merupakan sanksi memiliki ukuran tertentu di mana hakim tidak bisa mengurangi atau menambah. Batas beratnya sanksi telah ditentukan sebagaimana hadist Nabi SAW. Dari Tarmizi dari Amru bin Syu'aib dari bapaknya dari kakeknya, bahwa Rasulullah SAW bersabda, yang artinya: "barang siapa yang membunuh dengan sengaja, maka keputusnnya diserahkan kepada wali-wali pihak terbunuh. Mereka berhak membunuh, atau mengambil diat, yakni 30 unta dewasa, 30 unta muda (jadza'ah), dan 40 unta sedang bunting (khalfah), dan mereka juga berhak memaafkannya." ${ }^{30}$

Standar pembayaran diat pembunuhan adalah unta, ini menurut pendapat mayoriyas ulama dan pendapat yang dirajihkan (disahkan) Ibnul Qoyyim. Dengan dasar Hadist: Dari abdullah bin Amr ra. Bahwa Rasulullah SAW bersabda: "Ketahuilah bahwa diat pebunuhan yang mirip dengan sengaja yaitu yang dilakukan degan cambuk dan tongkat adalah seratus ekor unta. Di antaranya empat puluh ekor unta yang sedang hamil." (HR. Ibnu Majah dalam Syarh Sunan Ibnu Majah, Al-Hanafi 1999. Hadist No. 2627). ${ }^{31}$

Seluruh diat anggota tubuh dibayar dan diukur dengan unta, Syari'at selalu menentukan ukuran bagian diat dengan unta, sehingga menunjukkan bahwa unta adalah standar asal pembayaran diat. Menrut qaul jadid ketika tidak ditemukan unta maka berpindah pada harga unta-unta tersebut. Sedangkan menurut qaul qadim jika tidak ada unta maka boleh membayar 100 dinar atau 12.000 dirham. ${ }^{32}$

Mengenai besarnya diat yang harus dikeluarkan oleh terpidana bagi para korban, berdasarkan berbagai hadist Nabi terdapat beberapa variasi yang

${ }^{29}$ Muhammad Syahrur, Limitasi Hukum Pidana Islam, Walisongo Press, Semarang, 2008, hlm. 63

30 Abdurrahman Al-Maliki, Sistem Sanksi dalam Islam, Thariqul Izzah, Bogor, 2018, hlm. 129

${ }^{31}$ Paisol Burlian, Implementasi Konsep..., Op. Cit., hlm. 63.

32 Ibid. 
berbeda-beda. Namun demikian, secara umum dapat dikatakan bahwa diat pembunuhan itu adalah 100 ekor unta atau yang seharga dengan itu. Bahkan dalam penerapannya, menurut Imam syafi'i, Umar bin Khattab pernah menetapkan harga diat itu berbeda-beda untuk penduduk kota dan desa. Jika korban adalah penduduk kota, diatnya adalah 1000 dinar atau 200.000 dirham. Jika korbannya adalah penduduk desa, maka diatnya tetap 100 unta. 33

Kebijakan Umar demikian, nampanya dilakukan karena adanya perbedaan tingkat perkembangan antara penduduk kotan dan desa, baik perkembangan ekonomi, maupun perkembangan pendidikan. Artinya diat unta itu bersifat relatif dan dapat dinilai sesuai dengan situasi dan kondisi masyarakat setempat. Begitu juga pendapat Hasbi Ashshiddieqy, bahwa kadar diat tergantung kepada "urf" (perkembangan adat) dan kepada kerelaan kedua belah pihak. Bahkan lebih jauh menurut Hasbi, apabila si terpidana atau keluarganya tidak mampu membayar diat sedemikian itu, maka diat itu harus dibayar oleh kas negara. ${ }^{34}$

Penentuan berat ringannya sanksi pidana adalah bagian dari masalah kebijakan kerimanalisasi sanksi pidana. Pada hakikatnya masalah kebijakan hukum pidana bukanlah semata-mata pekerjaan teknik perundang-undangan yang dapat dilakukan secara yuridis normatif dan sistematik-dogmatik. Di samping pendekatan yuridis normatif, kebijakan hukum pidana juga memerlukan pendekatan pendekatan faktual yang dapat berupa pendekatan sosiologis, historis dan komparatif, bahkan memerlukan pula pendekatan komprehensif dari berbagai disiplin ilmu sosial, seperti ekonomi, dan ilmu sosial lainnya dan pendekatan integral dengan kebijakan sosial dan pembangunan nasional pada umumnya. Maka penentuan berat ringannya diat pembunuhan harus dilakukan secara rasional. Dengan melihat kondisi objektif sosial ekonomi masyarakat Indonosia.

Di dalam RUU KUHP telah dilakukan peningkatan kredibilitas pidana denda yang dilakukan baik terhadap berat ringannya maupun cara pelaksanaannya. Mengenai jumlahnya akan digunakan sistem kategori, sedangkan mengenai cara pelaksanaannya dapat diangsur dalam waktu yang

33 Abdurrahman Al-Maliki, Sistem Sanksi ..., Op. Cit., hlm. 110

34 Ibid. 
ditetapkan oleh Hakim. Dengan diterapkannya sistem kategori, di mana alasannya adalah untuk memudahkan perubahan apabila di kemudian hari terjadi perkembangan dalam nilai mata uang, hendaknya benar-benar menjadi pegangan utama untuk diperhatikan.

\section{Permaafan dan Diat dalam Konteks Pembaharuan Sanksi Pidana}

\section{Permaafan dalam RUU KUHP}

Permaafan diatur dalam RUU KUHP per September 2019 dalam Pasal 54 ayat (1). Huruf j. "Dalam pemidanaan wajib dipertimbangkan permaafan dari Korban dan/atau keluarganya". Dalam ketentuan ini permaafan hanya sebagai hal yang harus diperhatikan oleh hakim, karena terdapat kata wajib.

Dapat dipahami bahwa permaafan adalah suatu bentuk perdamaian yang dilakukan oleh pelaku dan korban untuk mengakhiri konflik. Permaafan tidak menghapus pidana, hanya menjadi pertimbangan hakim dalam menjatuhkan pidana. Dengan demikian hakim tetap menjatuhkan pidana atas pertimbangan karena telah memenuhi unsur-unsur pidana dan cukup alat bukti. Sebagaimana yang diatur dalam Pasal 183 KUHAP "Pasal 183 KUHAP berbunyi: "Hakim tidak boleh menjatuhkan pidana kepada seorang, apabila dengan sekurang-kurangnya dua alat bukti yang sah ia memperoleh keyakinan bahwa suatu tindak pidana benar-benar terjadi dan bahwa terdakwalah yang bersalah melakukannya".

Di negara-negara Eropa sudah mengenal dan mengatur permaafan oleh hakim. Atau yang disebut dengan rechterlij pardon atau non imposing of a penalty atau dispensa de pena, adalah dimana seorang terdakwa terbukti bersalah, tetapi tidak dijatuhkan pemidanaan oleh Majelis Hakim. Pengertian dari non imposing of penalty/ Rechterlijk Pardon/dispensa de pena mempunyai tujuan yang sama, yakni menyatakan seseorang terbukti secara sah dan meyakinkan, namun tidak menjatuhkan pemidanaan. Walaupun pemaknaan secara filosofis dari non imposing of penalty belum tentu didasarkan oleh konsepsi pemaafan hakim (bisa didasarkan hanya dari permasalahan penjara pendek, tetapi ketiganya 
mempunyai maksud yang sama untuk tidak menjatuhkan pidana sekalipun terdakwa terbukti). ${ }^{35}$

Konsep permaafan oleh hakim di negara-negara Eropa lebih maju dari Konsep permaafan dalam RUU KUHP. Permaafan diberikan oleh Hakim yang dikenal dengan istilah rechterlijk pardon. Belanda telah melakukan revisi WvS 1983 mengatur rechterlij pardon, melalui Undang-Undang 31-3-1983 Pasal 9a berbunyi: "The judge may determine in the judgement that no punishment or measure shall be imposed, where he deems this advisable, by reason of the lack of gravity of the offense, the character of the offender, or the circumstances attendant upon the commission of the offense or thereafter." 36 Kemudian diharmonisasikan ke dalam KUHAP Belanda, sehingga 4 kemungkinan dalam menjatuhkan suatu putusan oleh Majelis Hakim:

a. Pemidanaan atau penjatuhan pidana;

b. Putusan bebas (vrij spraak);

c. Putusan lepas dari segala tuntutan hukum (onslag van recht vervol ging); dan

d. Putusan Pemaafan Hakim (RechterlijkPardon).

Tim penyusun RUU KUHAP Tahun 2009, Pasal 187 RUU KUHAP berbunyi:

(1) jika hakim berpendapat bahwa hasil pemeriksaan di sidang tindak pidana yang didakwakan terbukti secara sah dan meyakinkan, maka terdakwa dipidana.

(2) jika hakim berpendapat bahwa hasil pemeriksaan di sidang tindak pidana yang didakwakan tidak terbukti secara sah dan meyakinkan, terdakwa diputus bebas.

(3) Jika hakim berpendapat bahwa perbuatan yang didakwakan kepada terdakwa terbukti, tetapi ada dasar peniadaan pidana, terdakwa diputus lepas dari segala tuntutan hukum.

Atas dasar ketiga jenis putusan hakim dalam RUU KUHAP tidak ditemukan permaafan hakim (rechterlijk pardon) yang menjatuhkan hukuman tanpa pidana. Pengaturan permaafan dalam RUU KUHP hanya memberikan pedoman kepada

35 Adery Syahputra, Tinjauan Atas Non-Imposing of a Penalty/ Rechterlijk Pardon/ dispensa de pena dalam RUU KUHP serta Harmonisasinya dengan RUU KUHAP, Diterbitkan oleh Institute for Criminal Justice Reform, Jakarta Selatan.

36 Tim Penyusun Terjemahan, The American Series of Foreign Penal codes (30 Netheralands), Fred B Rothman \& Co, Colorado, 1997, hlm. 38. Lihat juga Andi Zainal Abidin dan Andi Hamzah, Pengantar Dalam Hukum Pidana Indonesia, Yarsif Watampone, Jakarta, 2010, hlm. 170-171. Terjemahan: Jika hakim menganggap patut berhubungan dengan kecilnya arti perbuatan, kepribadian pelaku atau keadaan-keadaan pada waktu perbuatan dilakukan, begitu pula sesudah itu ia menunjukkan keteladanan, ia (hakim) dapat menentukan di dalam putusan bahwa tidak ada pidana atau tindakan yang dijatuhkan. (lihat Dalam Adery Ardhan Saputro. Konsepsi Rechterlijk Pardon Atau Pemaafan Hakim Dalam Rancangan KUHP). 
hakim sebagai pertimbangan dalam menjatuhkan pidana, bukan untuk membebaskan dari penjatuhan pidana.

\section{Permaafan dan Diat sebagai Pembaruan Hukum Pidana}

Permaafan dalam Hukum Pidana Islam adalah sebagai suatu pengampunan dari keluarga korban atas tindak pidana pebunuhan qishas-diat, hal ini berdasarkan firman Allah dalam surat Al-Baqoroh ayat 178. Para ahli figh sepakat bahwa adanya permaafan menggatikan pidana qishas menjadi pidana diat. Hanya yang diperselisihkan adalah apakah dengan permaafan otomatis menerbitkan diat sebagai pengganti kerugian atau diat harus ditentukan melalui mekanisme musyawarah perdamaian.

Dapat dipahami adanya perbedaan dalam permaafan dalam hukum Islam dengan RUU KUHP. Dalam hukum pidana Islam permaafan adalah pengampunan dari keluarga korban. Pengampunan menghapus pidana qishas dan menggatinya dengan pidana diat dalam tindak pembunuhan. Dengan adanya pengampunan maka hakim wajib menjatuhkan pidana diat dan menghapus pidana qishas.

Dalam RUU KUHP permaafan keluarga difahami sebagai pedoman hakim dalam menjatuhkan pidana hal yang meringankan hukuman, dan tidak menghapus hukukuman atau mengganti hukuman lain.

Praktik permaafan dengan perdamaian mengganti kerugian, mengakhiri konflik banyak ditemukan dalam masyarakat seperti telah diurai pada bagian terdahulu. Dari argumentasi di atas pembaharuan sanksi pidana pembunuhan memungkinkan permaafan bukan hanya menjadi pedoman hakim tetapi permaafan sebagai pengampunan keluarga korban yang menghapus pidana penjara menggantinya dengan pidana diat (penghapus pidana qishas). Hakim wajib menjatuhkan sanksi diat dan menghapus pidana penjara. Sanksi diat sebagai pengganti sanksi pidana penjara.

\section{Penutup}

Setelah melakukan kajian terhadap dua permasalahan di atas, disimpulkan sebagai berikut. Pertama, argumentasi yang mendukung perlunya sanksi permaafan dan diat sebagai sangksi alternatif pidana penjara, bahwa sanksi 
penjara adalah sanksi yang paling banyak dirumuskan bagi perbuatan pidana. Kebijakan ini berakibat kepada Penjatuhan pidana penjara paling banyak. Penyebab penghuni penjara penuh melampaui kapasitas (over capasity). Menyulitkan pembinaan, dan berujung pada kegagalan dalam mencapai tujuan pemidanaan, hal ini berpotensi menjadikan penjara tempat terjadinya tindak pidana baru (criminogen) sebagai akibat penyelenggaran sistem peradilan pidana yang buruk. Maka diperlukan alternatif pidana penjara pada tindak pidana pembunuhan biasa. Sumbangan tradisi pidana Islam dalam rangka pembentukan hukum pidana nasional mempunyai landasan teoritis yang kuat, mempunyai landasan filosofis Pancasila. Permaafan adalah asas yang terkandung dalam sila Ketuhanan Yang Maha Esa; sila kemanusiaan; selain itu juga mempunyai landasan Konstitusional UUD 1945 Pasal 29 ayat (1) dan (2). Dalam Pasal 29 ayat (1) ditegaskan bahwa Negara Berdasarkan atas Ketuhanan Yang Maha Esa. Kemudian dalam Pasal 29 ayat (2) ditegaskan bahwa Negara Republik Indonesia wajib menjalankan Syari'at agamanya, dan mempunyai landasan yuridis dalam berbagai undang-undang yang memberlakukan hukum Islam, dan landasan sosiologis penerimaan masyarakat terhadap hukum Islam. Kecenderungan sistem hukum berbagai negara menjadikan permaafan (rechterlijke pardon) untuk menghindari penjatuhan pidana penjara menjadikan permaafan dan diat sebagai sanksi baru, juga ikut mendukung.

Kedua, dalam penerapan pidana diat-qishas, hak penuntutan pidana (qishas atau diat) ada pada keluarga korban. Hakim wajib mempertimbangkan atas tuntutan keluarga korban dan menjatuhkan pidana diat apabila dimaafkan, sebagai pengganti pidana penjara, yang harus dibayar kepada keluarga korban sebagai ganti rugi. Pelaksanaan putusan hakim harus dijalankan segera setelah putusan hakim berkekuatan hukum tetap. Apabila denda diat telah dilaksanakan dengan baik oleh pelaku, maka hukuman qishas hapus (gugur). Artinya hukuman qishas segera dihapus apabila denda diat telah dibayar oleh pelaku kepada ahli waris korban.

Ketiga, sebagai pembaharuan sanksi, maka permaafan dan diat bukan sebagai pedoman hakim tetapi sebagai alasan pembebasan penjatuhan sanksi pidana penjara. Permaafan dalam rumusan RUU KUHP per September 2019 
bahwa permaafan yang telah dilakukan oleh korban dan pelaku hanya sebagai pedoman bagi hakim dan bukan sebagai alasan membebaskan pelaku dari pidana penjara. Sebagai pembaharuan hukum pidana nasional, maka perlu dimasukkan ke dalam RUU KUHP yang akan dibahas oleh legislatif.

\section{Daftar Pustaka}

\section{Buku}

Al-Maliki, Abdurrahman, Sistem Sanksi dalam Islam, Thariqul Izzah, Bogor, 2018.

Arief, Barda Nawawi, Kebijakan Legislatif dalam Penanggulangan Kejahatan Dengan Pidana Penjara, Universitas Diponegoro, Semarang, 1994.

Ashshiddiqie, Jimli. Pembaharuan Hukum Pidana Indonesia, Angkasa, Bandung, 1995.

Burlian, Paisol, Implementasi Konsep Hukuman Qihsash di Indonesia, Sinar Grafika, Jakarta, 2015.

Diantha, Imade Pasek, Metodelogi Penelitian Hukum Normatif dalam Justifikasi Teori Huku, Prenada media Group. Cet. Ke.1, Jakarta, 2016.

Fuady, Munir, Teori-teori Besar dalam Hukum (Grand Theori), Kencana Prenadamedia Group, Jakarta, 2013.

Marzuki, Peter Mahmud, Penelitian Hukum, Prenadamedia Group, Edisi revisi, Cet. Ke.7, Jakarta, 2014.

Supriyadi, Dedi, Sejarah Hukum Islam (dari Kawasan Jazirah Arab sampai Indonesia), CV. Pustaka Setia, Bandung, 2007.

Soekanto, Soerjono, dkk, Penelitian Hukum Normatif, Raja Grafindo, 1995 Soekanto, Soerjono, Pengantar Penelitian Hukum, UI. Press. Cet. Ke. 3, Jakarta, 1986.

Syahrur, Muhammad, Limitasi Hukum Pidana Islam, Walisongo Press, Semarang, 2008.

Thalib, Sayuti, Receptio A Contrario, Bina Aksara, Jakarta, 1985.

\section{Makalah}

Attamami, A. Hamid S., "Pancasila Cita Hukum dalam Kehidupa Hukum Bangsa Indonesia", Makalah, BP-7, 1991.

\section{Peraturan Perundang-undangan}

Kitab Undang-Undang Hukum Pidana Indonesia

Undang-Undang Republik Indonesia No. 11 Tahun 2012 tentang Sistem Peradilan Anak, (Lembaran Negara Republik Indonesia Tahun 2012 Nomor 153)

Rancangan Undang-Undang Republik Indonesia Nomor ... Tahun 2019 Tentang Kitab Undang-Undang Hukum Pidana, (Lembaran Negara Republik Indonesia Tahun ... Nomor ...) 
Undang-Undang Republik Indonesia Nomor 39 Tahun 1999 tentang Hak Asasi Manusia, (Lembaran Negara Republik Indonesia Tahun 1999 Nomor 165)

Undang-Undang Republik Indonesia Nomor 2 Tahun 2002 tentang Kepolisian Republik Indonesia, (Lembaran Negara Republik Indonesia Tahun 2002 Nomor 2)

Undang-Undang Republik Indonesia Nomor 22 Tahun 2009 tentang Lalu Lintas dan Angkutan Jalan, (Lembaran Negara Republik Indonesia Tahun 2009 Nomor 96)

Peraturan Mahkamah Agung (PERMA) Nomor 2 Tahun 2012 tentang Penyesuaian Batasan Tindak Pidana Ringan dan Jumlah Denda dalam KUHP,

Surat Kapolri No. Pol: B/3022/XII/2009/SDEOPS tentang Penanganan Kasus Melalui Alternatif Dispute Resolution (ADR)

\section{Website/Internet}

"Sistem data base pemasyarakatan", http://smslap.ditjenpas.go.id/, diakses 18 juni 2021

http://smslap.ditjenpas.go.id/public/grl/current/monthly. Diakses 14 September 2020

"Genoveva Alicia dalam konferensi pers di Jakarta" Error! Hyperlink reference not valid.. Diakses 14 sept. 2020

Supriyadi W. Eddyono Direktur Eksekutif ICJR. Diskusi kriminal dalam RKUHP dan bom waktu overcrowded Lapas di Jakarta, Rabu (15/11). 2017. https:/ / www.voaindonesia.com/a/banyak-aturan-pidana-penyebabpenjara-kelebihan-penghuni-/4116337. html. DIAKSES 14 OKT 2020.

\section{Masmedia/TV, Koran}

TV One. Berita sore. Rabu, 21 Maret 2018.

Kompas. "Lembaga pemasyarakatan tetap menjadi school of crime”. 4 April 2016. 